\title{
Extreme resistance to two Brazilian strains of Potato virus $Y$ (PVY) in transgenic potato, cv. Achat, expressing the PVYo coat protein.
}

\author{
Eduardo Romano; Adriana T. Ferreira²; André N. Dusi²; Karina Proite'; Jose A. Buso²; Antonio C. \\ Ávila²; Marta L. Nishijima²; Adriana S. Nascimento²; Fernando Bravo-Almonacid ${ }^{3}$; Alejandro \\ Mentaberry³; Damares Monte'; Magnólia A. Camposi'; Paulo Eduardo Melo²; Monica K. Cattony; \\ Antonio C. Torres ${ }^{2 *}$ \\ ${ }^{1}$ Embrapa Recursos Genéticos, P.O. Box 02372, 70.770-900 Brasília-DF, Brazil; ${ }^{2}$ Embrapa Hortaliças, P.O. Box 218, 70.359-970 \\ Brasília-DF, Brazil; ${ }^{3}$ INGEBI-CONICET y FCEN-UBA, Buenos Aires, Argentina
}

\section{SUMMARY}

The coat protein $(\mathrm{CP})$ gene of the potato virus Y strain "o" $\left(\mathrm{PVY}^{\mathrm{O}}\right)$ was introduced into potato, cultivar Achat, via Agrobacterium tumefaciens-mediated transformation. Sixty three putative transgenic lines were challenged against the Brazilian strains PVY-OBR and PVY-NBR. An extremely resistant phenotype, against the two strains, was observed in one line, denominated $1 \mathrm{P}$. No symptoms or positive ELISA results were observed in 16 challenged plants from this line. Another clone, named as 63P, showed a lower level of resistance. Southern blot analysis showed five copies of the $\mathrm{CP}$ gene in the extremely resistant line and at least three copies in the other resistant line. The stability of the integrated transgenes in the extreme resistant line was examined during several in vitro multiplications over a period of three years, with no modification in the Southern pattern was observed. The stability of the transgenes, the absence of primary infections and the relatively broad spectrum of resistance suggest that the extremely resistant line obtained in this work can be useful for agricultural purposes.

Keywords: Solanum tuberosum, GMO.

\section{RESUMO}

Resistência extrema a duas estirpes do Potato virus $Y$ (PVY) de batata transgênica, cv. Achat, expressando o gene da capa protéica do $\mathbf{P V Y}{ }^{\circ}$.

O gene da capa protéica (CP) do Potato virus $Y$ estirpe "o", foi introduzido em batata cultivar Achat, via Agrobacterium tumefaciens. Sessenta e três linhas possivelmente transgênicas foram desafiadas com as estirpes brasileiras PVY-OBR e PVY-NBR. Uma linha apresentou extrema resistência às duas estirpes inoculadas, e foi denominado clone 1P. Não foram observados sintomas sistêmicos de infecção e as plantas foram negativas em Elisa. Outra linha, denominada clone 63P, mostrou algum nível de resistência. Análises por Southern blot indicaram a presença de pelo menos cinco cópias do gen $\mathrm{CP}$ no clone $1 \mathrm{P}$ e pelo menos três cópias no clone 63P. A estabilidade do gene introduzido no clone 1P foi avaliada durante três anos, após várias multiplicações in vitro. Não foram observadas mudanças no padrão do Southern blot. A estabilidade do transgene, na ausência de infecções primárias e relativo largo espectro de resistência sugerem que o clone $1 \mathrm{P}$ pode ser utilizado para fins comerciais.

Palavras chaves: Solanum tuberosum, OGM.

(Accepted for publication in $21^{\text {th }}$ May, 2.001)

\begin{abstract}
Dotato virus $Y$ (PVY) belongs to the Potyvirus genus (Ward \& Shukla, 1991). Under field conditions, the virus is aphid transmitted in a non-persistant manner. Like the majority of plant viruses, has a single-stranded, positive sense RNA genome. The RNA is approximately $10 \mathrm{~kb}$ and, as a member of the family Potyviridae, has a 5'terminal genome-linked protein $(\mathrm{VPg})$ and a 3'poly(A) tail (Shukla et al., 1998). It contains a large open reading frame, which is translated into a large polyprotein that is processed by viral proteases into at least eight polypeptides. The coat protein (CP) gene is located at
\end{abstract}

the 3' end of the viral genome and its sequence has been established for several PVY strains (Bravo-Almonacid \& Mentaberry, 1989; Hay et al.,1989; Puurand et al., 1990; Robaglia et al., 1989; Thole et al., 1993; van der Vlugt et al., 1989; Wefels et al., 1989).

PVY infects potato (Solanum tuberosum) causing necrosis, mottling or yellowing-vein clearing of leaflets, leaf dropping and premature death (de Bokx, 1990). In fields established with infected tuber seeds, yield reduction is dramatic (De Bokx \& Piron, 1990; Brandolini et al., 1992). To avoid it, growers are compelled to a frequent renewal of tuber seed stocks, with lasting effects on production costs, growers' income, and final potato prices for consumers. PVY has been reported to infect potato in Brazil for at least 25 years (Alba \& Oliveira, 1976), although its actual importance has been masked for two decades by the joint occurrence of PLRV (Câmara et al., 1986). In 1994 severe losses exclusively due to PVY were reported, mainly on fields planted with cultivar Achat (Figueira, 1999). Achat is one important potato cultivar in Brazil (Torres et al, 1999).

Strategies to reduce losses by virus infection are based in the use of virus- 
free seed potatoes and special cultural practices (Gugerli, 1986). Usually these procedures do not offer permanent solutions to PVY infection. The development of resistant cultivars in potato can be a more effective strategy but, due to the tetraploid nature of its genome, potato breeding is known to be extremely difficult. However the ability to transform plants using Agrobacterium tumefaciens $\mathrm{Ti}$ plasmids has made it possible to produce plants with new traits without severe changes in the genetic background of the cultivar. CP mediated protection have been used in several crops to obtain transgenic plants resistant or tolerant to virus infection (Hull \& Davies, 1992).

Frequently, CP mediated protection results in resistance against the respective virus. This kind of resistance was observed with Tobacco mosaic virus, Alfalfa mosaic virus, Cucumber mosaic virus and both Potato virus $X$ and Potato Virus Y (Cuozzo et al., 1988; Lawson et al., 1990; Powell-Abel et al., 1986; Tumer et al., 1987). Resistance has also been found in potato. Farinelli et al. (1992) reported resistance (but not immunity) in transgenic potatoes expressing the $\mathrm{CP}$-gene of $\mathrm{PVY}^{\mathrm{N}}$. One line was completely resistant to $\mathrm{PVY}^{\mathrm{N}}$ and partially resistant to $\mathrm{PVY}^{\mathrm{O}}$. More recently, Hassairi et al. (1998) demonstrated for the first time a real heterologous immunity in potato: transgenic potatoes expressing the Lettuce mosaic virus (LMV) CP gene were extremely resistant to $\mathrm{PVY}^{\mathrm{O}}$.

This paper describes the introduction of the coat protein $(\mathrm{CP})$ gene of $\mathrm{PVY}^{\mathrm{O}}$ into potato $\mathrm{cv}$. Achat in order to produce transgenic plants with high resistance against PVY.

\section{MATERIAL AND METHODS}

\section{Genetic construction}

The CP gene from an international "o" strain, obtained from The International Potato Center (CIP), Peru, $\mathrm{PVY}^{\mathrm{O}}$ was previously cloned and sequenced (Bravo-Almonacid and Mentaberry, 1989). A sequence comprising the last 17 codons of the viral replicase, the $\mathrm{CP}$ gene, and the complete 3 ' non-coding region of the viral gRNA was contained in plasmid pBSY8. Appropriate elements for the initiation of translation were provided by an $88 \mathrm{bp}$ cDNA fragment contained in clone pUCY5. They comprised positions 113 to 201 of the PVY gRNA (Robaglia $e t$ al., 1989) and included part of gRNA 5' non-coding region, the AUG codon of the viral polyprotein and the first 5 codons of the P1 protein. To fuse both sequences in a continuos reading frame, the fragment from pUCY5 was digested with Xba I and Hinc II and ligated upstream of the pBSY8 sequence, creating pBSAUGCP. The recombinant polypeptide encoded by this sequence contains the cleavage site for the NIa viral protease (Riechmann et al., 1992). The whole sequence was removed from pBSAUGCP by digestion with $X b a$ I and Eco RV, and cloned in the binary expression vector pBI121 (Jefferson, 1987) previously treated with Sst I and T4 DNA polymerase to produce a blunt end, and digested with $\mathrm{Xba}$ I to excise the b-glucuronidase gene and generate compatible cloning sites.

\section{Plant transformation}

\section{Source of explant}

Axillary shoots of potato, cv. Achat, from virus free plants, established in vitro, were removed at 3 -weeks intervals and inter-nodal segments were excised and transferred to medium consisting of MS (Murashige \& Skoog, 1962) salts and, in $\mathrm{mg} \times \mathrm{L}^{-1}$ : sucrose 30,000 ; iinositol 100; thiamine- $\mathrm{HCl}, 1.0$; pyridoxine- $\mathrm{HCl}, 0.05$; nicotinic acid, 0.05; glycine, 2.0; naftaleneacetic acid (NAA), 0.05; kinetin (Kin), 0.05; giberellic acid (GA3) 0.2; and Phytagar (Sigma) 7,000. Cultures were kept at $25^{\circ} \mathrm{C}$ and illuminated for $16 \mathrm{~h}$ per day with $62 \mathrm{mmolm}^{-2} \mathrm{~s}^{-1}$ of cool white fluorescent light.

Agrobacterium strain and growth conditions

Agrobacterium tumefaciens LBA4404 carrying plant transformation vector $\mathrm{pBI}-\mathrm{PVY}$ containing the $\mathrm{PVY}^{\circ}$ coat protein gene and NPT II gene were used. The bacteria grew in medium consisting of Lurias broth (LB) (bactotryptone, 10 g..$^{-1}$; bacto-yeast-extract, 5 g. $1^{-1}$; and sodium chloride, 10 g..$^{-1}$ ) supplemented with kanamycin (kan), 50 mg. $1^{-1}$ and streptomycin (Str), $300 \mathrm{mg} .1^{-}$
${ }^{1}, \mathrm{pH} 7.5$ before autoclaving. Antibiotics were cold sterilized using Pro-X 0.22 $\mathrm{mm}$ membrane filtration before being added to cooling medium. Cultures for transformation experiments were inoculated in $250 \mathrm{ml}$ Erlenmeyer flasks containing $50 \mathrm{ml}$ of LB medium with Kan and Str. Inoculated flasks were placed in an orbital shaker $(0,175 \mathrm{~g}, 150$ $\mathrm{rpm}, \mathrm{r}=10 \mathrm{~mm})$, at $28^{\circ} \mathrm{C}$ and cultures grown overnight to $\mathrm{A}_{600}=0.8$. Culture aliquots of $15 \mathrm{ml}$ were centrifuged at 5,000 rpm (Beckman J2-21, JA-20 rotor) for $10 \mathrm{~min}$ at $4{ }^{\circ} \mathrm{C}$. The supernatant was discarded and the pellets were resuspended in $15 \mathrm{ml} \mathrm{LB}$ medium (Torres et al., 1993).

\section{Explant transformation}

Nodal segments were dipped into bacterial suspension for $10 \mathrm{~min}$, blotted with sterile filter paper and cocultivated for $48 \mathrm{~h}$ on shoot initiation medium containing MS (Murashige \& Skoog, 1962) salts and, in $\mathrm{mg} \times \mathrm{l}^{-1}$ : sucrose 30,000; i-inositol 100; thiamine- $\mathrm{HCl}$, 1.0; pyridoxine- $\mathrm{HCl}, 0.05$; nicotinic acid, 0.05; glycine, 2.0; ribosilzeatin (Zea), 3,0; and Phytagar (Sigma) 7,000. After cocultivation, explants were immersed for $30 \mathrm{~min}$ in $200 \mathrm{ml}$ of MS salts, $3 \%$ sucrose with $100 \mathrm{mgl}^{-1}$ of cefotaxime (Cef) and $500 \mathrm{mgl}^{-1}$ carbenicillin (Carb). Explants were then placed in selection/shoot initiation medium containing Kan at $50 \mathrm{mgl}^{-1}$, Cef $100 \mathrm{mgl}^{-1}$ and Carb $500 \mathrm{mgl}^{-1}$. Following shoot initiation, surviving plantlets were transferred every 14 days to fresh medium. For rooting, plantlets were transferred to medium containing MS salts, vitamins and $0.5 \mathrm{mg} . \mathrm{L}^{-1}$ of indole3-butyric acid.

Plant inoculation with PVY strains and virus detection

Two PVY strains were used for resistance evaluation, PVY-OBR and PVY-NBR (Inoue-Nagata et al., in press). PVY-OBR is an ordinary strain collected from potato, which causes mottling and pearl spots symptoms in Nicotiana tabacum plants. PVY-NBR is a necrotic strain isolated from potato and causes necrosis in N. tabacum. Both strains were maintained in $N$. tabacum plants under mechanical inoculation.

Potato plants to be inoculated were grown from virus-free tubers obtained 
originally from the 63 different in vitro explants screened in selective media $\left(\mathrm{kan}^{+}\right)$. Three plants per genotype were used: two plants were inoculated with each of the PVY strains and the third was kept virus-free and grown together as a negative control. The inoculation was conducted two to three weeks after emergence and consisted rubbing the potato leaves previously dusted with Carborundum with a PVY infected macerate of Nicotiana tabacum leaves at $1: 10$ dilution in $0.01 \mathrm{M}$ phosphate buffer plus $1 \%$ sodium sulfite. The plants were inoculated twice, with the same PVY strain, over 48 hours. Nontransformed virus-free potato plants, cultivar Achat, were also inoculated and used as a positive control. The clones that did not show symptoms were selected. New tubers of these plants were planted and the plants were inoculated in the same way as described above, using eight plants per clone and two viral dilutions in the inoculation suspension: 1:20 and 1:40. ELISA was performed 15 and 21 days after the first inoculation, using polyclonal antibodies against PVY in a double antibody sandwich format (Clark \& Adams, 1977). All bioassays were performed under controlled conditions to avoid aphids and to prevent any risk of environmental spread of transgenic material.

\section{Southern blot analysis}

Genomic DNA from non-infected putative transgenic and non-transformed Achat plants was extracted from young leaves (Dellaporta et al., 1983). Twenty mg of DNA from each sample were digested with Eco RI or Xba I (Eco RI cuts twice in $\mathrm{CP}$ gene releasing the whole gene and $\mathrm{X} b a$ I cuts once in the T-DNA). The products of digestion were separated on a $0.9 \%$ agarose gel and blotted onto Hybond-N membrane (Amersham, USA). Hybridization was carried out using the $\mathrm{CP}$ or $n p t$ II gene ${ }^{32} \mathrm{P}$-labeled probes (Sambrook et al., 1989).

\section{RESULTS AND DISCUSSION}

In this study, transgenic plants of the potato cultivar Achat were obtained, which showed extreme resistance to Brazilian strains PVY-OBR and PVY-
NBR. Sixty-three kanamycin resistant plants were regenerated in genetic transformation experiments and they were mechanically and isolatedly inoculated with the two Brazilian PVY strains. Two clones, $1 \mathrm{P}$ and 63P, showed no symptoms, as well as negative results for PVY in ELISA, and were selected for further analysis. Other clones, were either moderately resistant (showed delayed and attenuated symptoms) or were completely susceptible.

In a second round of assays, after micropropagation, the resistant clones were challenged with the two PVY strains. Line 63P showed some phenotypic abnormalities, smaller tubers and slower plant growth, when compared to non-transformed plants. Two out of 16 plants of the 63P clone showed milder symptoms and the virus could be detected by ELISA. The clone $1 P$ showed no symptoms and a negative ELISA assay. This clone was considered to be extremely resistant to both strains of PVY.

Southern blot with DNA digested with Eco I revealed the presence of at least three copies of the npt II gene in both lines 1P and 63P (Figure 1). The intense hybridization bands observed in clone 1P, when compared with clone 63P indicated that the number of copies of the introduced gene in line 1P may be higher than in the line 63P. Additional Southern hybridization of total genomic DNA digested with $\mathrm{Xba}$ I (cuts once in the $\mathrm{CP}$ gene) indicated that the line $1 \mathrm{P}$ has probably five copies of the $\mathrm{CP}$ gene (Figure 2). Since the construction pBIPVY used in transformation experiments has an open reading frame, theoretically the resistance could be protein mediated.

The stability of the integrated transgenes in the extreme resistant clone $1 \mathrm{P}$ was examined by Southern blotting hybridization. Potato is an asexually propagated plant and during the process of transformation by Agrobacterium, chimeric plants can be obtained. Therefore it is important to analyze wether, after several generations of propagation, the introduced transgenes are stable in the acceptor genome. Consequently, a comparative Southern blot analysis was performed with DNA

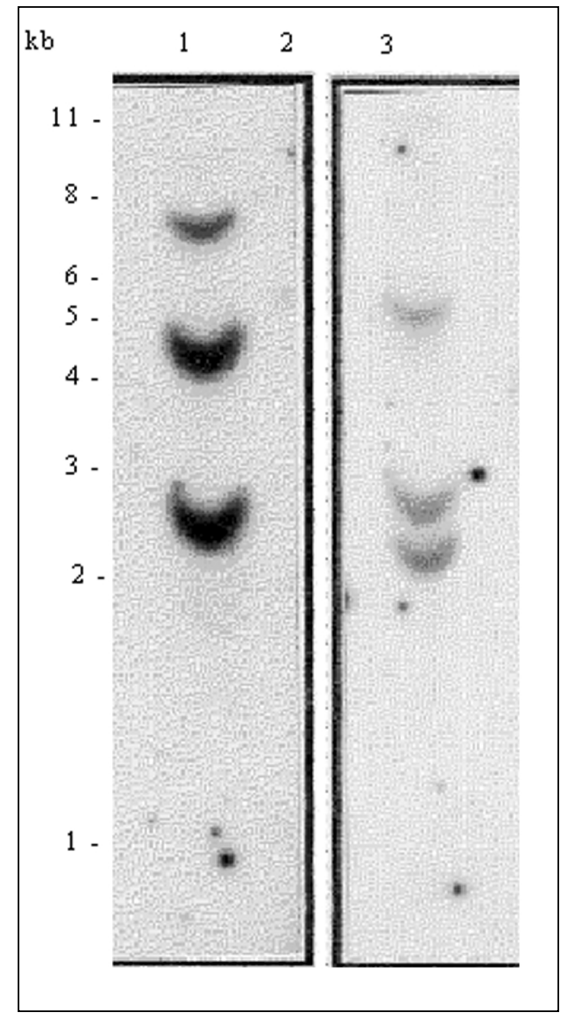

Figure 1. Southern blot hybridization of genomic DNA from potato plants transformed with pBI-PVY t-DNA (lanes 1 and 3) and control plant (lane 2). Genomic DNA was digested with Eco RI and hybridization was carried out using npt II gene ${ }^{32} \mathrm{P}$-labeled probes. Lane 1- Clone $63 \mathrm{P}$ showing at least three copies of the integrated npt II gene. Lane 3- Clone $1 \mathrm{P}$ showing at least three copies of the integrated npt II gene. Brasília, Embrapa Hortaliças, 2.000.

extracted from the primary transformant and DNA from the same line after several in vitro multiplications in a period of three years. The same pattern was obtained for the two DNA preparations (Figure 2), indicating that the integrated transgenes were stably mantained during the vegetative propagation. In the case of potato, this is a very important feature, as vegetative propagation is how potato seedtubers are obtained.

The homology degree of the CP gene used in the transformed plants (from $\mathrm{PVY}^{\circ}$ ) with the PVY-OBR and PVYNBR is respectively 95.9 and $93.3 \%$ (Inoue-Nagata et al., in press). It is believed that a broad spectrum resistance can result in a stable resistance in the field and thus, the most pressing practical need for transgenic 


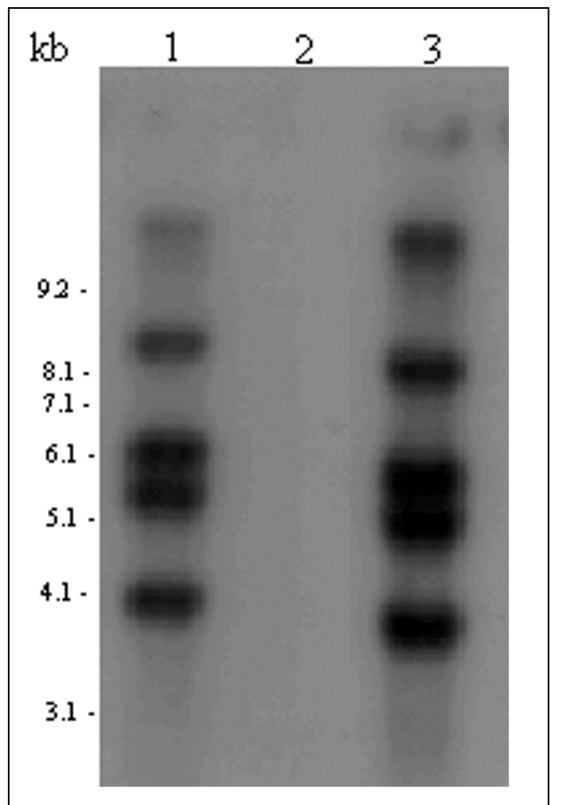

Figure 2. Southern hybridization of genomic DNA from potato plants transformed with $\mathrm{pBI}-$ PVY t-DNA and control plant, showing the number of copies and stability of the integrated transgenes in clone $1 \mathrm{P}$. Genomic DNA was digested with $\mathrm{Xba}$ I and probed with a fragment of the CP-gene. Lane 1: clone 1P from primary transformant; lane 2: untransformed potato; lane 3: clone $1 \mathrm{P}$ after several in vitro multiplications over a three years period. Brasília, Embrapa Hortaliças, 2.000.

resistant plants is for high-level, broad spectrum resistance (Baulcombe, 1996).

In this study we selected two highly resistant potato lines, $1 \mathrm{P}$ and 63P, against two PVY strains, in transgenic potato cv. Achat. The two lines were twice challenged and, the 1P line did not allow systemic virus multiplication and symptom expression. This line also demonstrated stability of the integrated transgenes over a period of three years, after successively in vitro multiplications. The stability of the transgenes, the absence of primary infections and the relatively broad spectrum of resistance suggests that this line can be used for agricultural purposes. However, greenhouse experiments can only give an indication of plant performance. Thus, field experiments are being conducted to confirm wether this transgenic line has retained all the agronomic characteristics of "Achat", and the resistance, under natural disease pressure.

\section{ACKNOLEDGMENTS}

The authors thank the Brazilian Conselho Nacional de Desenvolvimento Científico e Tecnológico (CNPq) for the grants and to the program RHAE Biotecnologia, to the Centro Brasileiro Argentino de Biotecnologia (CBAB) and to the FAP-DF for the partial financial support to this work.

\section{LITERATURE CITED}

ALBA, A.P.C.; OLIVEIRA, A.R. Serological studies on viruses of the potato virus $\mathrm{Y}$ group occurring in Sao Paulo State. Summa Phytopathologica, v. 2, p. 178-184, 1976.

BAULCOMBE, D.C. Mechanisms of pathogenderived resistance to viruses in transgenic plants. Plant Cell, v. 8, p. 1833-1844, 1996.

BRANDOLINI, A.; CALIGARI, P.D.S.; MENDOZA, H.A. Combining resistance to potato leafroll virus (PLRV) with immunity to potato viruses $\mathrm{X}$ and $\mathrm{Y}$ (PVX and PVY). Euphytica, v. 61, p. 37-42, 1992.

BRAVO-ALMONACID, F.; MENTABERRY, A.N. Nucleotide cDNA sequence coding for the PVYo coat protein. Nucleic Acids Research, v. 17, p. 4401, 1989.

CÂMARA， F.L.A.; CUPERTINO, F.P.; FILGUEIRA, F.A.R. Incidência de vírus em cultivares de batata multiplicadas sucessivamente em Goiás. Fitopatologia Brasileira, Brasília, v. 11, p. 711-716, 1986.

FIGUEIRA, A.R. Viroses da batata: situação atual e perspectivas futuras. Informe Agropecuário, Belo Horizonte, v. 20, p. 86-96, 1999.

CLARK, M.F.; ADAMS, A.N. Characteristics of the microplate method of enzyme linked immunosorbent assay for the detction of plant viruses. Journal of Genetic Virology, v. 34, p. 475483, 1977.

CUOZZO, M.; O'CONNELL, K.M.; KANIEWSKI, W.; FANG, R.X.; CHUA, N.H.; TUMER, N.E. Viral protection in transgenic tobacco plants expressing the mosaic virus coat protein or its antisense RNA. Biotechnology, v. 6, p. 549-557, 1988.

DE BOKX, J.A. Potato virus Y. In: Compendium of potato disease. St. Paul: APS Press; 1990, p. 70-71.

DE BOKX, J.A.; PIRON, P.G.M. Relative efficiency of a number of aphid species in the transmission of potato virus $\mathrm{Y}$ in the Netherlands. Netherlands Journal of Plant Pathology, v. 96, p. 237-246; 1990.

DELLAPORTA, S.L.; WOOD, J.; HICKS, J.B. A plant DNA minipreparation: version II. Plant Molecular Biology Report, v. 1, p. 19-21,1983.

FARINELLI, L.; MALNOE, P.; COLLET, G.F. :Heterologous encapsidation of potato virus $Y$ strain $\mathrm{O}$ (PVY-O) with the transgenic $\mathrm{CP}$ of $\mathrm{PVY}$ strain $\mathrm{N}$ (PVY-N) in Solanum tuberosum cv Bintje, Biotechnology, v. 10, p. 1020-1025, 1992.
FIGUEIRA, A.R. Viroses da batata: situação atual e perspectivas futuras. Informe Agropecuário, Belo Horizonte, v. 20, p. 86-96, 1999.

GUGERLI, P. Potato viruses. In: BERGMEYER, H.U., ed. Methods of enzimatic analysis-. antigens and antibodies 2.. $\mathrm{Vol} 11 . \quad \mathrm{VCH}$ Verlagsgesellschaft, Weinheim, FRG; 1986, p. 430-446.

HASSAIRI-A; MASMOUDI-K; ALBOUY-J; ROBAGLIA-C; JULLIEN-M; ELLOUZ-R. Transformation of two potato cultivars 'Spunta' and 'Claustar' (Solanum tuberosum) with lettuce mosaic virus coat protein gene and heterologous immunity to potato virus Y. Plant-ScienceLimerick,v. 136, p. 31-42; 1998.

HAY, J.M.; FELLOWES, A.P.; TIMMERMAN, G.M. Nucleotide sequence of the coat protein gene of a necrotic strain of potato virus $Y$ from New Zealand. Arch Virol.; v. 107, p. 111-22, 1989

HULL, R.; DAVIES, J.W. Approaches to nonconventional control of plant virus diseases. Critical Reviews in Plant Sciences, v. 11, p. 1733, 1992.

INOUE-NAGATA, A.K.; FONSECA, M.E.N.; LOBO, T.O.T.A.; ÁVILA, A.C.; MONTE, D.C. Analysis of the nucleotide sequence of the coat protein and 3'-untranslated region of two Brazilian potato virus Y isolates. Fitopatologia Brasileira, Brasília, in press.

JEFFERSON, R.A.; KAVANAGH, T.A.; BEVAN, M.W. GUS fusions: beta-glucoronidase as a sensitive and versatile gene fusion marker in higher plants. EMBO Journal, v. 6, p. 3901-3907, 1987.

LAWSON, C.; KANIEWSKI, W.; HALEY, L.; ROZMAN, R.; NEWELL, C.; SANDERS, P.; TUNER, N. E. Engineering resistance to mixed virus infection on a commercial potato cultivar: resistance to potato virus $\mathrm{X}$ and potato virus $\mathrm{Y}$ in transgenic Russet Burbank. Bio/Technology, v. 8, p. 127-134, 1990.

MURASHIGE, T.; SKOOG, F. A revised medium for rapid growth and bioassays with tobacco tissue cultures. Physiologia Plantarum., v. 15, p. 473497, 1962.

POWELL-ABEL, P.; NELSON, R.S.B., HOFFMANN, N; ROGERS, S.G.; FRALEY, R.T.; BEACHY, R.N. Delay of disease development in transgenic plants that express the tobacco mosaic virus coat protein gene. Science, v. 232, p. 738-743, 1986.

PUURAND, U.; SAARMA, M. Cloning and sequencing of the 3'-terminal region of potato virus YN (Russian isolate) RNA genome. Nucleic Acids Research, v. 18, p. 6694; 1990

RIECHMANN, J.L.; LAÍN, S.; GARCÍA, J.A. Highlights and prospects of potyvirus molecular biology. Journal of Genetic Virololgy, v. 73, p. 116,1992 .

ROBAGLIA, C.; DURAND-TARDIF, M.; TRONCHET, M.; BOUDAZIN, G.; ASTIERMANIFACIER, S.; CASSE-DELBART, F. Nucleotide sequence of potato virus $\mathrm{Y}$ (N Strain) genomic RNA. Journal of Genetic Virology, v. 70, p. $935-47,1989$.

SAMBROOK, J.; FRITSCH, E.F.; MANIATIS, T. Molecular cloning: a labaratory manual. $2^{\text {nd }}$ Edition. New York: Cold Spring Harbor Laboratory Press, 1989. 
SHUKLA, D.D.; WARD, C.W.; BRUNT, A.A.; BERGER, P.H. Potyviridae family. Descriptions of plant viruses, AAB, 1998.

THOLE, V.; DALMAY, T.; BURGYAN, J.; BALAZS, E. Cloning and sequencing of potato virus Y (Hungarian isolate) genomic RNA. Gene, v. 123, p. 149-561, 1993.

TORRES, A.C.; CANTLIFFE, D.J.; LAUGHNER, B.; BIENIEK, M. NAGATA, R.; FERL, R.J. Stable transformation of lettuce cultivar South Bay from cotyledon explants. Plant Cell, Tissue and Organ Culture, v. 34, p. 279-285, 1993.
TORRES, A.C.; NAGATA, R.T.; FERL, R.J.; CANTLIFFE, D.J.; BEWICK, T.A. In vitro assay selection of glyphosate resistance in lettuce. Journal of the American Society for Horticultural Science, v. 124, n. 1, p. 86-89, 1999.

TUMER, N.E.; O'CONNELL, K.M.; NELSON, R.S.; SANDERS, P.R.; BEACHY, R.N.; FRALEY, R.T.; SHAD, D.M. Expression of alfafa mosaic virus coat protein gene confers crossprotection in transgenic tobacco and tomato plants EMBO Journal, v. 6, p. 1181-1188;1987.
VAN DER VLUGT, R.; ALLEFS, S.; DE HAAN, P.; GOLDBACH, R. Nucleotide sequence of the 3'-terminal region of potato virus YN RNA. Journal of Genetic Virology, v. 70, p. 229-233, 1989.

WARD, C.W.; SHUKLA, D.D. Taxonomy of potyviruses: current problems and some solutions. Intervirology, v. 32, p. 269-297, 1991.

WEFELS, E.; SOMMER, H.; SALAMINI, F.; ROHDE, W. Cloning of the potato virus Y genes encoding the capsid protein $\mathrm{CP}$ and the nuclear inclusion protein NIb. Arch Virology, v. 107, p. 123-34,1989

SCHMIDT, D.; SANTOS, O.S.; BONNECARRÈRE, R.A.G; MARIANI, O.A.; MANFRON, P.A. Desempenho de soluções nutritivas e cultivares de alface em hidroponia. Horticultura Brasileira, Brasília, v. 19, n. 2, p. 122-126, julho 2.001.

\section{Desempenho de soluções nutritivas e cultivares de alface em hidroponia ${ }^{1}$.}

\section{Denise Schmidt; Osmar S. Santos; Reinaldo Antonio G. Bonnecarrère; Odacir Antonio Mariani; Paulo Augusto Manfron \\ UFSM. Depto. Fitotecnia - 97.105-900, Santa Maria - RS. E-mail: 9960006@alunop.ufsm.br}

\section{RESUMO}

Foi conduzido um experimento em estufa plástica na Universidade Federal de Santa Maria (RS), com o objetivo de avaliar a eficiência de soluções nutritivas sobre a produtividade de cultivares de alface (Aurora, Lívia, Regina, Brisa, Mimosa e Verônica) em hidroponia. $\mathrm{O}$ experimento foi realizado no período de outubro a dezembro de 1998, em delineamento experimental de blocos ao acaso, com duas repetições. Avaliou-se sete soluções nutritivas recomendadas por Ueda na sua formulação completa; Castellane \& Araujo (50\% e $100 \%$ da concentração); Furlani (50\% e $100 \%$ da concentração); Bernardes (50\% e $100 \%$ da concentração). Os resultados demonstraram que as soluções nutritivas completas, recomendadas por Castellane \& Araujo e Furlani foram as mais eficientes na produção de alface. A solução nutritiva Ueda apresentou a menor produtividade, mesmo quando comparada com as soluções diluídas (50\%). As cultivares Regina e Mimosa mostraram os melhores desempenhos e a cultivar Aurora mostrou pouca adaptação para cultivo nessa época do ano.

\begin{abstract}
Efficiency of nutrient solutions and performance of lettuce cultivars in hydroponics.

The efficiency of seven different hydroponic solutions was evaluated on the yield of six lettuce cultivars (Aurora, Lívia, Regina, Brisa, Mimosa and Verônica). The experiment was performed from October to December 1998, in a randomized blocks designed with two replications. The nutrient solution recommended by Ueda was analyzed in its complete formulation (100\%), and Castellane \& Araujo; Furlani; and Bernardes in its complete and half formulation of nutrients concentration (100\% and 50\%). The nutrient solutions recommended by Castellane \& Araujo; and Furlani, without dilution $(100 \%)$, resulted in higher yield. The use of Ueda nutrient solution resulted in the lowest yield, even when compared with diluted solutions (50\%). Regina and Mimosa cultivars presented the best performance and Aurora the worst one.
\end{abstract}

Keywords: Lactuca sativa, soilless culture, hydroponic conditions.

Palavras-chave: Lactuca sativa, cultivo sem solo, cultivo hidropônico.

\section{(Aceito para publicação em 09 de abril de 2.001)}

\begin{abstract}
A hidroponia é uma técnica de cultivo de plantas em meio líquido que tem se expandido no mundo todo como meio de cultivo de hortaliças, pois permite o plantio durante todo o ano, além de atender perfeitamente às exigências de produção com uniformidade, alta qualidade, alta produtividade, desperdício mínimo de água e nutrientes e o mí-
\end{abstract}

nimo uso de defensivos agrícolas (Alberoni, 1998).

No Brasil, a hidroponia está bastante disseminada. Em praticamente todos os Estados cultiva-se nesse sistema, principalmente a alface (Teixeira, 1996). Essa espécie é a mais difundida entre os produtores por se tratar de cultura de fácil manejo e por ter ciclo curto, garantindo rápido retorno do capital investido (Koefender, 1996). No mercado estão disponíveis muitas cultivares de alface, mas pouco se sabe a respeito de suas adaptações à hidroponia, não havendo recomendação de cultivares para esse sistema de cultivo (Gualberto et al., 1999).

Um aspecto fundamental para o sucesso do cultivo hidropônico é a esco

\footnotetext{
${ }^{1}$ Parte da Dissertação de Mestrado em Agronomia da primeira autora, área de concentração em Produção Vegetal, pela Universidade Federal de Santa Maria (UFSM).
} 